\section{Til fest i Gewandhaus}

\author{
afforfatter, red. afCarl Nielsen Brevudgaven \\ John Fellow
}

\section{Vejen til Blomstedt}

Skrevet til programheftet ved Herbert

Blomstedts 50-ärs jubileumskoncert som dirigent med Gewandhausorkestret i Leipzig den 24.6.2004.

$\mathrm{V}$ i kom begge til København i efteråret 1967, Herbert Blomstedt som ny chef for det danske radiosymfoniorkester, jeg som nybagt student for at studere ved universitetet. Da det ikke skulle ligne en tilfældighed, havde der været et forspil: På en udflugt til Sverige i mit sidste skoleår havde jeg købt en plade med svensk musik, Hilding Rosenbergs 2. symfoni, dirigent Herbert Blomstedt. De nordiske lande har hver én stor komponist, bortset fra Sverige som til gengæld har sangerne og dirigenterne, sagde man. Det sidste var ikke forkert, det forste en tvivlsom sandhed, fortalte pladen mig.

Kort tid efter optrådte "professor Herbert Blomstedt fra Stockholm" - som koncertprogrammet, uvant udforligt og respektfuldt, skrev - endda med det lokale orkester i Odense, hvor jeg trådte mine børnesko. Med kort varsel reddede han situationen ved den faste dirigents pludselige afbud. Den dag hørte jeg Dvoraks 8. og havde aldrig hørt noget lignende. Med tilfredshed læste jeg dagen efter i avisen, stadig med Bøhmen i ørerne, at denne mand skulle være chefdirigent i København. Så var der lidt at falde tilbage på hvis læreanstalterne skulle vise sig alt for professorale.

Efter 67 kom 68 med det mislykkede Prager-forår i øst der skulle kalde Herbert Blomstedt til Staatskapelle Dresden, og $\mathrm{i}$ vest det anderledes succesrige ungdomsoprør, der gav os der ikke blot slog en kolbøtte i rette tid, en del at slås med. Vi var et par kammerater der ikke havde musikken som fag, men dyrkede den både i og uden for fritiden. Mens anden vestlig ungdom kastede arvegods over bord og fik sig en anden musik, søgte vi mod den klassiske arv som vi ikke havde med hjemmefra, og fandt i den bl.a. et middel til at holde sammen på os selv. Vi blev stampublikum og nåede de hundrede koncerter under Blomstedts xgide.

Til den ny musik kom vi opladte, til klassikerne forberedte, kendte allerede indspilningerne med de store gamle, Walter, Furtwängler, Klemperer, og det gik op for os at vi var vidne til noget der tålte sammenligning. Der var i de år, skønt orkestret var midt i et vanskeligt generationsskifte, større kræfter på spil i de københavnske koncertsale end i læreanstalternes auditorier, før og efter kolbøtterne.

Også Celibidache optrådte ofte i København, unægteligt en anden type, bjergtagende perfektionist, men tit på kant med både værk og publikum som han ikke kunne få sig selv til at bukke for. Det kvitterede med vild applaus som han nægtede at modtage, og når publikum endelig forlod salen uden at have kunnet kalde idolet frem igen, kunne det finde ham udenfor ved pølsevognen med en læderjakke over kjoleskøderne i gang med de bayerske pølser. Så nær kom vi aldrig vegetaren Blomstedt.

Mens Celibidache dæmpede sidestemmer ned til det uhørlige, lod dem være et klangtæppe under hovedstemmen, 


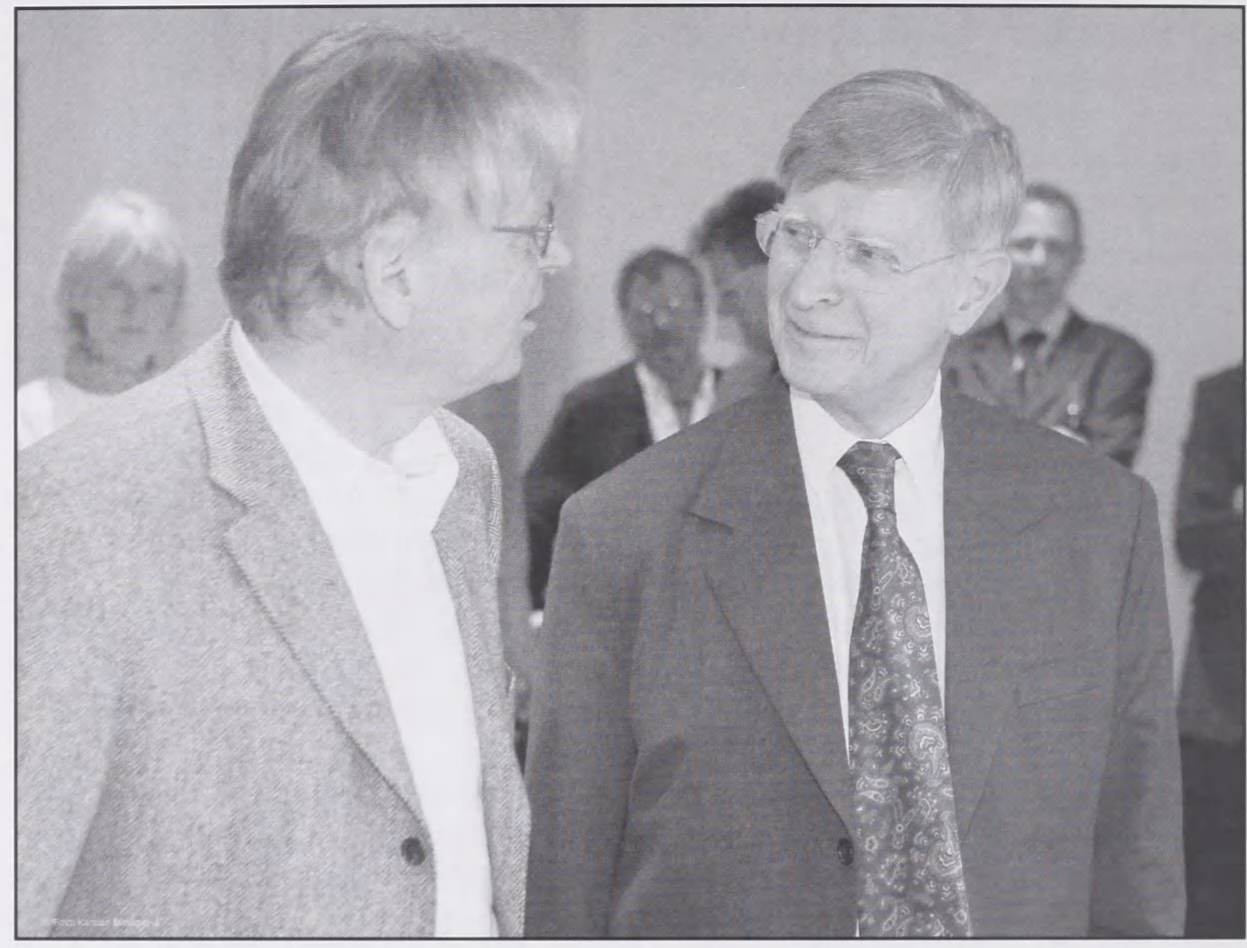

Herbert Blomstedt (t.h.) i samtale med John Fellow ved presentationen af forste bind af Carl Nielsen Brevudgaven. Presentationen fandt sted i Det Kongelige Biblioteks Blixen-sal maj 2005.

stod udenfor og manipulerede og byggede op så hatten passede, lod Blomstedt alle stemmer komme til deres ret og strømme frit $\mathrm{i}$ indbyrdes afstemthed, og når musikkens formforløb og dynamik kulminerede, kom det indefra som et resultat af stemmernes sam- og modspil. Det lød også som en livsholdning. Det var ham der kom Beethoven, Brahms, Bruckner, Nielsen, alle de andre og vort hjerte nærmest. Da han spillede Schuberts 9., løste han tilmed striden imellem os om Walters og Furtwänglers indspilninger: De havde begge fundet deres overmand. Jeg svævede i Schubert i flere nætter, min kammerat spiste i nattevildelse en bid af programmet og viste mig år senere stolt resterne med tandmærkerne.
Det kom ikke bag på os at vores dirigent en dag rejste. Vi ventede på at verden skulle opdage hvad vi allerede havde opdaget, og da indspilningerne kom fra

Dresden og San Francisco, var det som at få sin ungdom bekræftet. Vi havde ikke taget fejl, den var mere end en ungdommelig rus i musik.

En skønne dag førte mit forfatterskab mig i nærheden af musikkens forgemak, da jeg udgav Carl Nielsens samlede skrifter. Herbert Blomstedt var netop havnet i dens helligdom, Gewandhaus. Nu havde jeg en gave hvormed jeg kunne betale en brøkdel af gælden tilbage. Da Frau Pless efter en koncert førte mig ad den lange gang hvor alle tiders berømte Gewandhaus- 
kapellmeistre hænger på rad og række,

Nikisch, Walter, Furtwängler, Abendroth ..... og deres lyslevende efterfølger til sidst stod i den åbne dør, fik jeg åndenød og hjertebanken. Måske hævnede den respektløshed hvormed jeg i min ungdom på skift havde kasseret flere af dem, sig nu. Jeg havde kendt Blomstedt altid, men kendte han mig? Mens dirigentens navn står i programmet, og hans person og psyke afslører sig ikke så lidt i den klingende musik, er selv stampublikummet mere anonymt.

Hjertet holdt: Over midnat blev der stadig talt i Gewandhauskapellmeisterens kontor.

Nu gjaldt det en udgave af Carl Nielsens tusinder af breve, for heller ikke danskerne kender rigtig deres komponist endnu, men pengene kunne ikke skaffes. En dag ringer telefonen i København. Blomstedt efter en generalprøve i Gewandhaus:

- Jeg har spurgt mig selv hvad jeg kan gøre. Kan det sætte noget i gang at jeg kommer og giver en række koncerter og donerer mit honorar til en brevudgave?

Nu kommer Carl Nielsen Brevudgaven, mindst 10 bind, det første før skiftedag i Gewandhaus.

Vi er begge blevet ældre siden dengang i København da kun den ene af os stod i programmet. Aldersforskellen synes mindre, og det sker at jeg er i tvivl om hvem der er ældst. Jeg nåede ikke begyndelsen for 50 år siden, men er dybt taknemmelig for de 37 år det allerede er blevet til - og for at være med i Gewandhaus zu Leipzig i dag ved begyndelsen til det næste halve århundrede.

\section{Blomstedt og Gewandhaus}

Laudatio $i$ Gewandhaus den 1.7.2005 ved festkoncerten i anlening af Herbert Blomstedts fratreden som Gewandhauskapellmeister

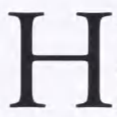
vem er Herbert Blomstedt? Men vi ved det jo alle! I syv år har han været Gewandhauskapellmeister, den 18. i rækken af store berømte musikere som Mendelssohn, Nikisch, Furtwängler, Walter, Abendroth, Konwitschny, Neumann og Masur.

Men hvordan nærmer vi os denne mand, denne dirigent der kan sige at dirigenten er en uinteressant person i musikoplevelsen? "Det er musikken der skal tale, og jeg ser det som min opgave at musikken skal tale så meget som muligt og jeg så lidt som muligt." - Hvad driver dette menneske?

Som søn af en svensk adventistpræst og en pianistinde havde han fra begyndelsen valget imellem religionen og musikken. Han valgte begge dele. Musikken blev en kilde til kontakten med tilværelsens religiøse grundlag, til kontakten med de religiøse værdier. Sangen blev, med hans eget udtryk, en prædiken. Sangen skulle ikke blot synge, den skulle også tale, hvor svært det end er at oversætte denne tale til ord, tale om alt menneskeligt i dets forbundethed med det største. I de store klassiske værker fandtes alt dette i en mere almen form end i de religiøse læresætninger og dogmer. I koncertsalene kunne der prædikes for et større publikum end i kirkerne.

Det er intet tilfælde at Anton Bruckner står Herbert Blomstedts nær, og at han nu ved sin fratrædelseskoncert spiller hans 8. symfoni, et af musikhistoriens største og dybeste bygningsværker, den sidste Bruckner fuldførte.

Bruckner var også et religiøst 


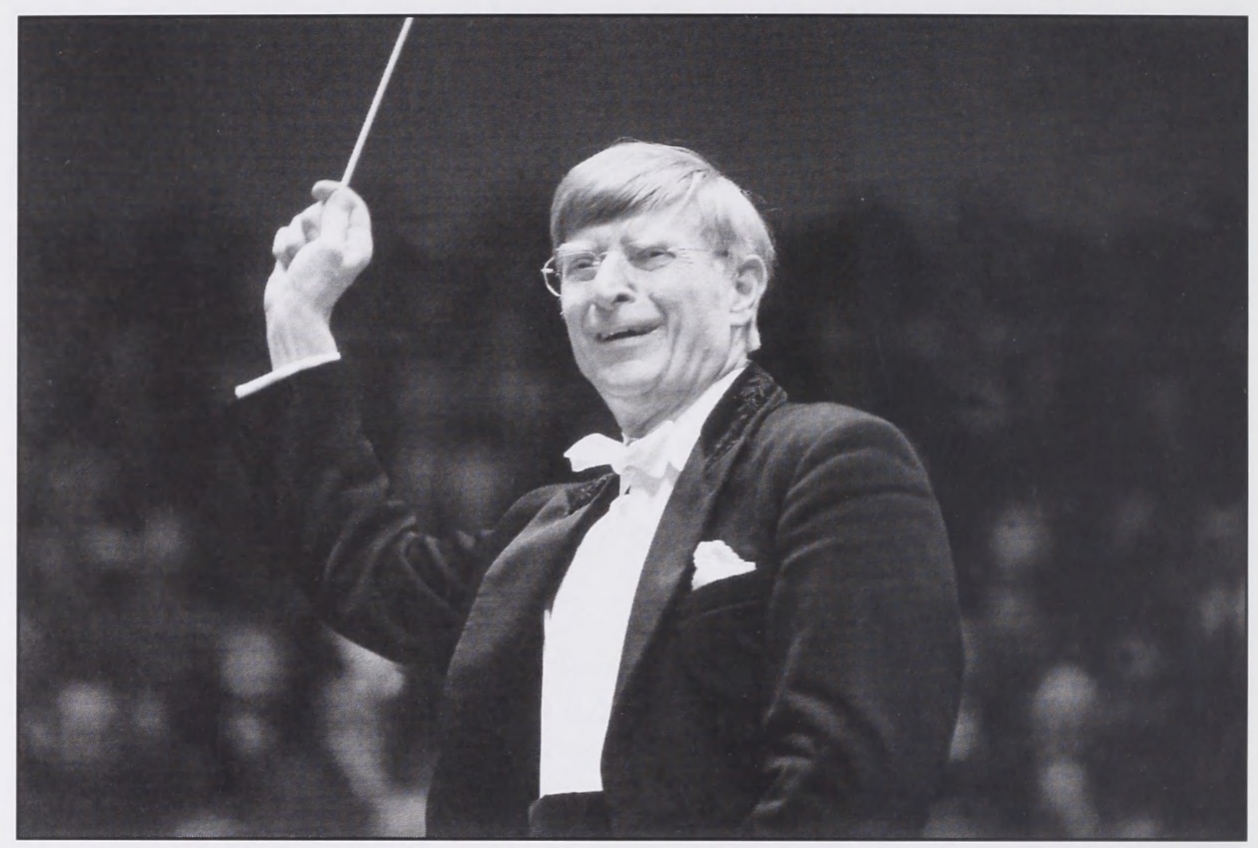

Herbert Blomstedt på podiet i Gewandhaus i Leipzig.

menneske, glødende katolik. I det verdslige 19. århundrede, hvor kirkemusikken havde mistet sin dominerende stilling, var han den religiøse musiker par excellence, og dog blev han ikke kort og godt kirkemusiker, skrev ikke kun messer og motetter, men gav symfonien en ny dimension og stræbte mod koncertsalene.

Blomstedt blev heller ikke blot kantor eller barokspecialist, helligede sig ikke simpelthen de sakrale århundreders rigdomme af musik, men bevægede sig ind i de verdslige koncertsale, åbnede sit religiøst dogmatiske udgangspunkt for det alment eksistentielle og bevarede og fasthold det religiøse grundlag. Som Bruckner gjorde det som komponist!

Den vej er som skabt for Gewandhaus, passer til de gamle ord af Seneca: Res severa verum gaudium, en alvor- lig sag er en sand glæde, som har prydet alle tre Gewandhaüser. Passer for Leipzig hvor religion, kunst og politik altid og helt frem til den nyeste historie har været tæt sammenknyttet? I Leipzig er koncertsalen en helligdom, her lytter man med andagt, her åbner man dørene for politikken, som kirkerne gør det, her er de religiøse og de åndelige værdier en del af modstanden, elementerne er til stede i forskellige kombinationer i både kirken, koncertsalen og på rådhuset. Her er noget at bevare!

Gewandhausorkestret var engang et avantgardeorkester, her fandt den første samlede opførelse af Beethovens 9 symfonier sted endnu mens Beethoven levede. Det var Arthur Nikisch' opførelse af Bruckners 7. symfoni i Leipzig dagen før nytårsaften 1884 der åbnede den musikalske verdens øjne for denne vidunderlige 
usamtidige komponist. Rækken af historiske uropførelser kunne fortsættes. Også her har udgangspunktet paradoksalt nok ført til at der er noget at bevare, en tradition at holde i hævd.

\section{Ja, hvad er Gewandhaus og}

Gewandhausorkestret? Som hverken Leipziger eller tysker er jeg ikke den rette til at svare, men Gewandhaus har vi alle lov til at have en mening om, i hvert fald skal vi, hvor i verden vi end bor, ikke bevæge os mange skridt ind i den klassiske musik før vi kender navnet og tænker på Gewandhaus og Leipzig som noget særligt.

Gewandhaus har mere end en gang skabt historie uden for Leipzig og Tyskland. Wien er ikke den eneste musikby Leipzig har sat på plads, også København blev sat på plads da Mendelssohn spillede Niels W. Gades 1. symfoni efter at Musikforeningen i København havde nægtet at røre værket, og som den senere organisator af det københavnske musikliv havde Gade sin autoritet fra posten som Mendelssohns efterfølger i Gewandhaus. Siden har danske musikere valfartet til Leipzig.

Da den 11. Gewandhauskapellmeister, Wilhelm Furtwängler, i 1927 opførte Carl Nielsens 5. symfoni, blev der igen skrevet dansk musikhistorie i Gewandhaus. Det var den største succes Danmarks største komponist oplevede i sin levetid, og dermed var der sået et frø i Gewandhaus, som den 18. Kapellmeister, dagens hovedperson, har bragt til fuld udfoldelse. Med $\sin$ Beethoven-Nielsen-cyklus har han introduceret alle Carl Nielsens symfonier og koncerter i Gewandhaus, ikke af veneration for sin nordiske hjemstavn, men af kærlighed til den europæiske tradition som Gewandhausorkestret er så stærkt forbundet med, og som især to nordiske komponister, Carl Nielsen og Jean Sibelius er en videreførelse af og originale bidrag til. Det danske musikliv som engang fik en afgørende impuls fra Leipzig og Gewandhaus, har nu via svenskeren og verdensborgeren Herbert Blomstedt sendt $\sin$ fornemste frugt tilbage til musikbyen.

Hvis noget i dansk musikliv har europæisk og global adresse, er det Carl Nielsens anderledes svar på den musikalske og bevidsthedsmæssige krise som Europa befandt sig i ved forrige århundredskifte, og som vi siden snarere har gravet os dybere ned i end ud af. Polariseringen mellem bevidsthedsdræbende og bevidstgørende musik er ikke blevet mindre i det forløbne århundrede. I Wien var og måtte svaret blive isolation, mens Carl Nielsen - i kraft af den han var, og i kraft af en stærk dansk folkelig tradition - kunne kaste sig ud i en pædagogisk sangproduktion som skulle bringe det store publikum i nærheden af den store musik. Dette kulturelle projekt er i dag også i Danmark glemt og blæst omkuld af de seneste årtiers kulturelle skred i Vesten, et skred som siden die Wende også er blevet en udfordring for musikbyen Leipzig - og for hele verden.

Endnu engang har Gewandhaus gjort sin indflydelse gældende i Danmark. Da pengene til den store Carl Nielsen Brevudgave ikke kunne skaffes, donerede den 18. Gewandhauskapellmeister sit honorar for en serie Carl Nielsen-koncerter i Skandinavien, og sparkede dermed et stort kulturhistorisk projekt i gang. Det blev alt sammen aftalt og grundlagt her i Gewandhaus under Nielsen-Beethoven koncerterne i oktober 2000. Mens det store kulturelle drama i Nielsens 5 . symfoni udspillede sig for fuldt orkester, og kan genhøres i den cd-box som netop er udkommet, greb kapelmesteren også ind i virkelighedens drama og lagde grundstenen til en ny beskæftigelse med en af den nære fortids kulturelle korsveje. 


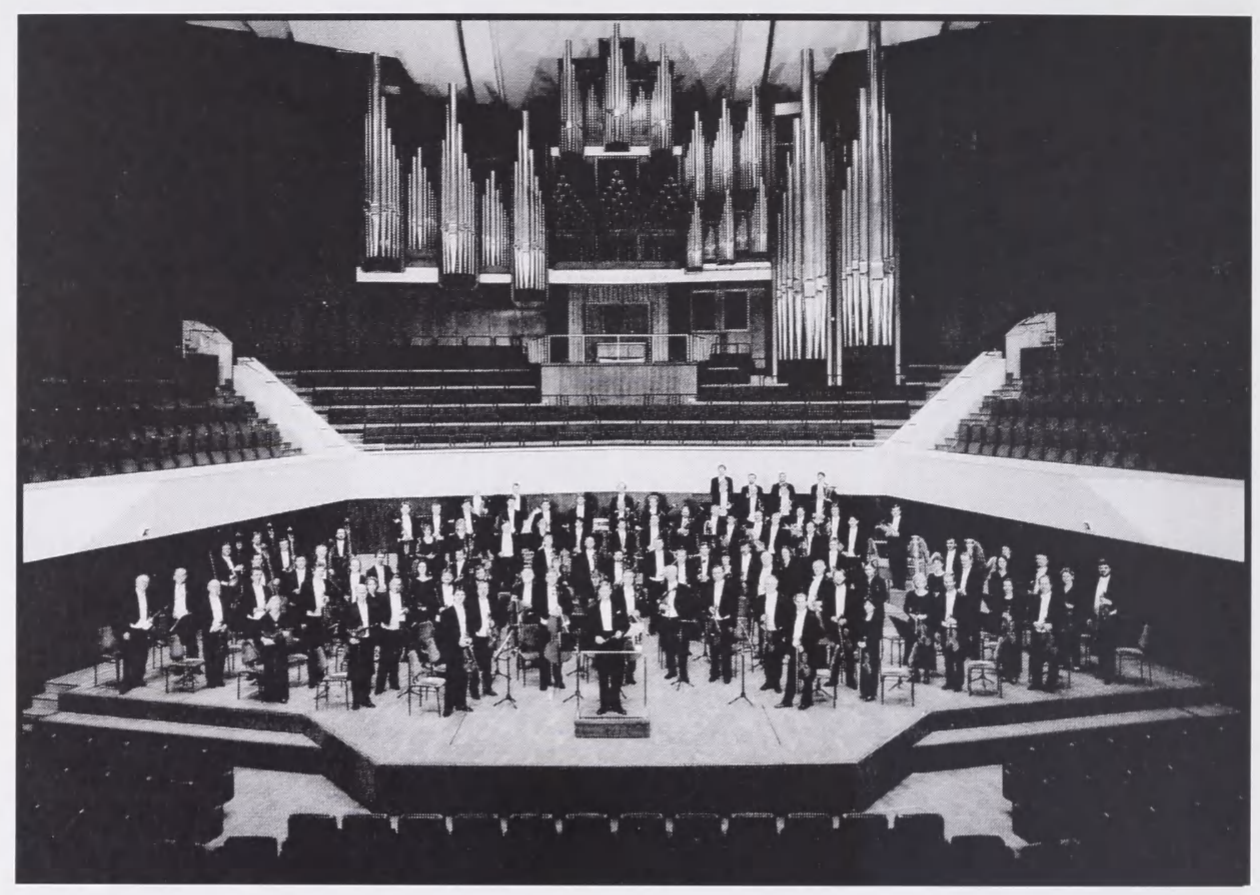

Gewandhausorkestret og Herbert Blomstedt. Fra sasonen 1999/2000. Det gamle koncerthus blev odelagt under 2. verdenskrig, og forst i 1970 erne var de okonomiske forudsatninger for opforelsen af en ny koncertsal tilstede. Det nye, 3., Gewandhaus blev indviet i 1981. - Fra Rudolf Skoda: Die Leipziger Gewandhausbauten, Berlin 2001.

Musikeren Blomstedt har jeg kendt i 38 år, siden min studentertid. Hans musiceren, hans evne til at tale i musik, var fra begyndelsen en særlig oplevelse som satte standarder for de enkelte værker og for meningen med en koncert - og med livet. Efter en Blomstedt koncert havde man altid været i en anden verden, men var ikke længere kun samtidig. Der var altid et nærvær af de usædvanlige på grundlag af et perspektiv som ikke knyttede sig til moden og tidsånden. Her var en åndelig kraft, og en åndelig modstand imod den kulturelle opløsning.

At det netop var Dresden han rejste til da han forlod København, undrede os ikke. I vesten vidste en del musikmennesker godt at den klassiske musik i det besatte Østeuropa, det egentlige gamle Centraleuropa, havde en langt større livskraft og kulturel betydning end i Vesten, måske desværre i kraft af den politiske misere. Her var stadig den rene vare, og i den var der både åndelig og politisk modstandskraft, og når det ikke var nyhedsudsendelser, men musik vi ønskede at høre i radioen, stillede vi ofte ind på østeuropæiske stationer. Også i København gik vi efter plader med Gewandhausorkestret og Staatskapelle Dresden.

Som unge i det fri og rige Vesten havde vi brug for den åndelige modstandskraft som I bag jerntæppet var nødt til at præstere! Og når Günter Grass i dag spørger hvor modstandskraften mod "den sidste tilbageværende ideologi" findes, så er svaret at 
den findes bl.a. ret fortolket i hele den klassiske kanon af mesterværker som

Gewandhaustraditionen bygger på. Men tradition er i vor tid ikke slendrian, det er et konstant arbejde for at holde forbindelsen til vores grundlag og vore rødder $\mathrm{i}$ live.

\section{Kære Herbert!}

At netop du skulle blive Gewandhauskapellmeister i denne kulturelle og politiske situation, kan ikke være noget tilfælde. Du havde modstandskraften på begge sider i den todelte verden, og du har den nu hvor den sy- nes at smuldre overalt. Du har været den fødte Gewandhaus-kapellmeister.

Dog ikke i alle henseende. Dine 17 forgængere var gennemsnitligt 40 år da de tiltrådte og 53 da de fratrådte. Du tiltrådte som 71-årig og i denne måned fylder du 78. Alligevel forlader du ikke posten for at lade dig pensionere, du ved sikkert slet ikke hvad det ord betyder, og derfor ønsker jeg med sindsro Gewandhausorkestret, dets publikum og gæster, dig selv og os alle mange gensyn endnu, mange fælles oplevelser også i fremtiden. 